\title{
Investigations of geometrical structure and morphology of samples made of hard machinable materials after wire electrical discharge machining and vibro-abrasive finishing
}

\section{Untersuchung der Oberflächenstruktur und Morphologie von schwer zu bearbeitenden Metalllegierungen nach elektroerosivem Drahtschneiden und Vibrationsschleifbearbeitung}

\author{
M. Gołąbczak ${ }^{1}$, P. Maksim¹, P. Jacquet ${ }^{2}$, A. Gołąbczak ${ }^{3}$, K. Woźniak \\ C. Nouveau ${ }^{5}$
}

In this article the results concerned influence of processing conditions of the wire electrical discharge machining and vibro-abrasive machining on the surface layer and morphology of samples made of hard machinable materials used in aircraft industry like: Titanium $5553 \beta$, Inconel 617, Hastelloy X and Magnesium AZ31 have been presented. For this purpose the cubic and cylindrical samples made of hard machinable alloys have been prepared using optimal electric parameters of wirecut electrical discharge machining and finally they have been polished using circular vibratory finishing technology and different ceramic shaped stones.

Keywords: Wire electrical discharge machining / circular vibratory surface finishing / ceramic shaped stones / hard machinable alloys / surface geometrical structure / surface roughness

Im Artikel werden Untersuchungsergebnisse von schwer zu bearbeitenden Metalllegierungen aus der Flugzeugindustrie nach dem Einsatz von elektroerosivem Drahtschneiden und der Vibrationsschleiftechnik in Bezug auf Rauheit und Oberflächenstruktur dargestellt. Zu diesen gehören: Titan 5553 B-Legierung, Inconel 617, Hastelloy $X$ und Magnesium AZ31-Legierung. Zu diesem Zweck wurden Proben in Würfel- und Zylinderform mit elektroerosivem Drahtschneiden ausgeschnitten und

1 Institute of Machine Tools and Production Engineering, Lodz University of Technology, Stefanowskiego 1/15 Street, 90-924 ŁÓDŹ, REPUBLIC OF POLAND

2 École Catholique des Arts et Métiers, 40 Montée Saint-Barthélemy, 69321 LYON, FRENCH REPUBLIC

3 Higher Vocational State School in Włocławek, 3 Maja 17 Street, 87-800 WŁOCŁAWEK, REPUBLIC OF POLAND

4 MARBAD Ltd. Company, Kulczyńskiego 14 Street, 02-777 WARSZAWA, REPUBLIC OF POLAND

5 Arts et Métiers Paris Tech, Rue Porte de Paris, 71250 CLUNY, FRENCH REPUBLIC

Corresponding author: M. Gołąbczak, Institute of Machine Tools and Production Engineering, Lodz University of Technology, Stefanowskiego 1/15 Street, 90924 ŁÓDŹ, REPUBLIC OF POLAND,

E-Mail: marcin.golabczak@p.lodz.pl 
mittels der Vibrationsschleiftechnik unter Anwendung von keramischen Schleifmitteln fertigbearbeitet.

Schlüsselwörter: Elektroerosives Drahtschneiden / Fertigbearbeitung mit Vibrationsschleiftechnik / keramische Schleifmittel / schwer zu bearbeitende Metalllegierungen / geometrische Struktur der Oberfläche / Oberflächenrauheit

\section{Introduction}

In this article the investigation results concerning estimation of the conditions of the wire electrical discharge machining (WEDM) process and vibro-abrasive machining on the surface layer, roughness and morphology of machined aerospace alloys like Magnesium AZ31, Hastelloy X, Inconel 617 and Titanium $5553 \AA$ are presented. The AZ31 magnesium alloy is characterized by very low density $(1.8 \mathrm{~g} /$ $\left.\mathrm{cm}^{3}\right)$, has very low hardness $(70 \mathrm{HB})$ and tensile strength $(350 \mathrm{MPa})$. The melting point of $\mathrm{AZ} 31$ magnesium alloy is only $600{ }^{\circ} \mathrm{C}$. $\mathrm{Mg}$ alloys are used where weight reduction is necessary, i.e. in motorization and aeronautics. The titanium 5553 beta alloy has higher density $\left(4.6 \mathrm{~g} / \mathrm{cm}^{3}\right)$ and hardness (370 HB) and has extremely high tensile strength (1350 MPa). The melting point of titanium beta alloy is also very high, at $1670{ }^{\circ} \mathrm{C}$. Titanium alloys are used in production of many parts of planes and medical implants. Nickel alloys like Inconel 617 and Hastelloy $\mathrm{X}$ have very high density $\left(8.2 \mathrm{~g} / \mathrm{cm}^{3}\right)$ and hardness $(300 \mathrm{HB})$ and have high tensile strength (700 MPa). The melting point of nickel alloys is very high (up to $2000{ }^{\circ} \mathrm{C}$ ). They are used in the production of blades for turbines [1-3]. The range of investigations has covered wire electrical discharge machining of these alloys in optimal conditions of electrical parameters of impulse generator and comparatively tests of vibro-abrasive machining using special kind of ceramic shaped stones [4-7].

\section{Work-stand, method and experimental conditions}

The aim of the work was to measure surface texture and surface geometrical structure of superalloys after two stages of their machining: Wire electrical discharge machining using Accutex AU-500 iA wire electrical discharge machine and vibro-abrasive machining using Eraba circular vibratory sur- face finishing machine and different ceramic shaped stones manufactured in Marbad Ltd. Company (Warsaw, Poland) [4-6]. For assessment of morphology of aircraft alloys in 2D and 3D configuration after each stage of machining the Olympus DSX-HRSU (ENSAM, Cluny, France) optical profiling system (ECAM, Lyon, France) has been used. For investigations two kind of samples in shape of cube and cylinder have been cut using wire electrical discharge machining technology. The cubic samples had the dimension $20 \mathrm{~mm} \times 20 \mathrm{~mm}$ however cylindrical samples $\varnothing 20 \mathrm{~mm} \times 20 \mathrm{~mm}$.

\section{Assessment of geometrical structure of surface layer of aircraft alloys after wire electrical discharge machining process}

Presented investigation results have concerned assessment of stereometric surface parameters (SGP) and morphology of the surface layer of samples made of selected aircraft alloys like: Hastelloy X, Magnesium AZ31, Inconel 617 and Titanium 5553 $ß$ after wire electrical discharge machining process, Table 1. Analysis of obtained results shows significant changes in morphology and the shape of the surface geometrical structure of samples made of aircraft alloys after wire electrical discharge machining process, Figures $1-4$.

\section{Assessment of geometrical structure of surface layer of aircraft alloys after vibro-abrasive machining}

Presented investigation results have concerned assessment of stereometric surface parameters and the morphology of the surface layer of selected aircraft alloys like: Hastelloy X, Magnesium AZ31, Inconel 617 and Titanium 5553 ß after vibro-abrasive machining process (finishing) using ceramic shaped stones, Figures 5-9 [8-12]. 
Table 1. Parameters of WEDM process.

Tabelle 1. Prozessparameter beim elektroerosivem Drahtschneiden.

\begin{tabular}{|c|c|c|c|}
\hline \\
\hline \multicolumn{2}{|c|}{ Kinematical parameters } & \multicolumn{2}{|l|}{ Electrical parameters } \\
\hline $\begin{array}{l}\text { Cutting speed }-v_{c} \\
{\left[\mathrm{~mm}^{2} / \mathrm{min}\right]}\end{array}$ & 50 & $\begin{array}{l}\text { Working voltage }-U \\
\text { [V] }\end{array}$ & 80 \\
\hline $\begin{array}{l}\text { Wire feed }-w_{f} \\
{[\mathrm{~mm} / \mathrm{s}]}\end{array}$ & 180 & $\begin{array}{l}\text { Working current }-I \\
{[\mathrm{~A}]}\end{array}$ & 15 \\
\hline $\begin{array}{l}\text { Wire tension }-w_{t} \\
\text { [g] }\end{array}$ & 1000 & $\begin{array}{l}\text { Impulse duration } \\
\text { time }-t_{\text {on }}[\mu s]\end{array}$ & 0.5 \\
\hline $\begin{array}{l}\text { Water pressure - } \\
w_{p}[\mathrm{kPa}]\end{array}$ & 20 & $\begin{array}{l}\text { Impulse break time } \\
-t_{\text {off }}[\mu \mathrm{s}]\end{array}$ & 8 \\
\hline
\end{tabular}

Technical characteristic of wire: copper wire $\varnothing 0.25 \mathrm{~mm}$ Dielectric: deionized water Machine: Accutex AU-300iA CNC Wirecut (EDM) Type of coolant: demineralized water

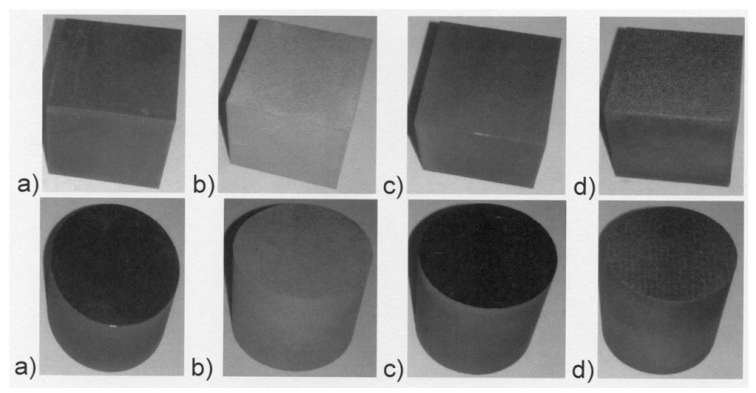

Figure 1. Exemplary pictures of cubic and cylindrical superalloy samples after WEDM: a) Hastelloy X, b) AZ31Mg alloy, c) Inconel 617, d) Ti 5553 B alloy (magnification $5 \times$ ).

Bild 1. Beispielfotos der würfel- und zylinderförmigen Proben nach elektroerosivem Drahtschneiden aus folgenden Metalllegierungen: a) Hastelloy X, b) Magnesium AZ31-Legierung, c) Inconel 617, d) Titan 5553 B-Legierung (5-fache Vergrößerung).

\section{Conclusions}

Presented investigation results have concerned assessment of stereometric surface parameters and the morphology of the surface layer of selected aircraft alloys like after wire electrical discharge machining and vibro-abrasive machining process (finishing) using ceramic shaped stones. The investigations carried out have enabled the estimation of optimal electrical conditions of the wire electrical discharge machining of preparation samples made of hard machinable alloys like AZ31 magnesium alloy, titanium beta alloy, Inconel 617 and Hastelloy X. Investigation results of the
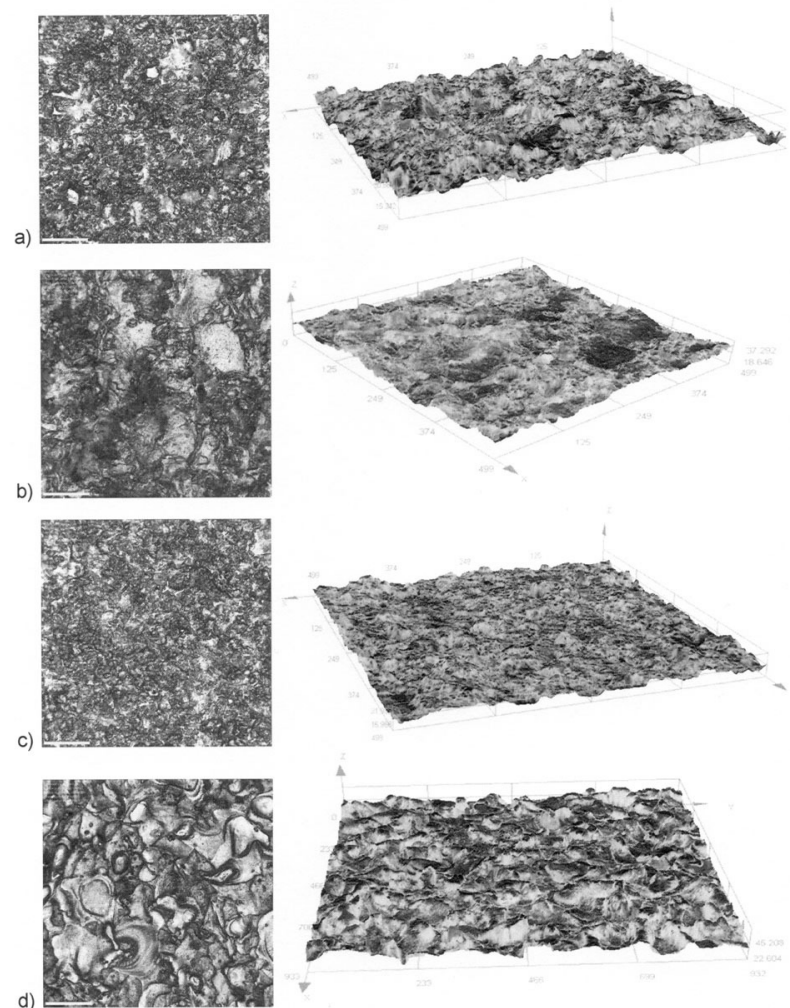

Figure 2. Microstructure images of superalloy samples after Wire EDM: a) Hastelloy X, b) AZ31 Mg alloy, c) Inconel 617, d) Ti $5553 \mathrm{~B}$ alloy (magnification 100x).

Bild 2. Bilder der Mikrostruktur folgender Metalllegierungen nach elektroerosivem Drahtschneiden: a) Hastelloy X, b) Magnesium AZ31-Legierung, c) Inconel 617, d) Titan 5553 ßLegierung (100-fache Vergrößerung).

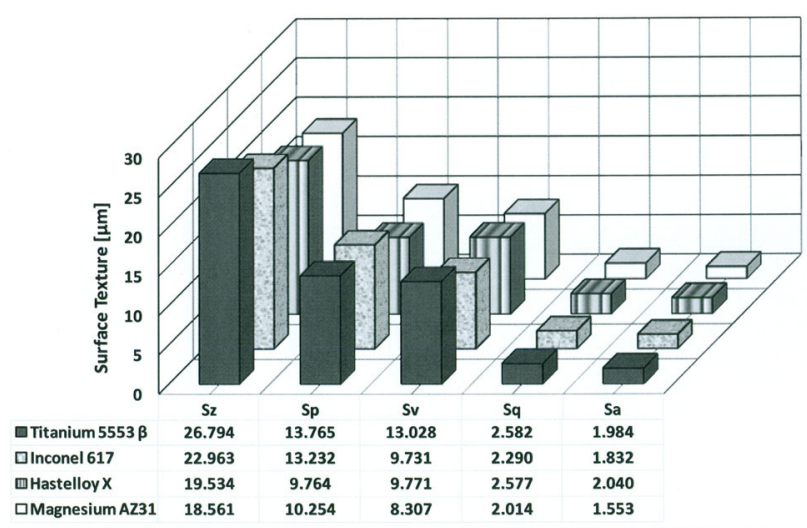

Figure 3. Stereometric surface layer parameters $\left(S_{z}, S_{p}, S_{v}\right.$, $S_{q}, S_{a}$ ) of superalloy samples after wire EDM.

Bild 3. Stereometrische Parameter der Oberfläche $\left(S_{z}, S_{p}\right.$, $S_{v}, S_{q}, S_{a}$ ) der Metalllegierungen nach elektroerosivem Drahtschneiden. 


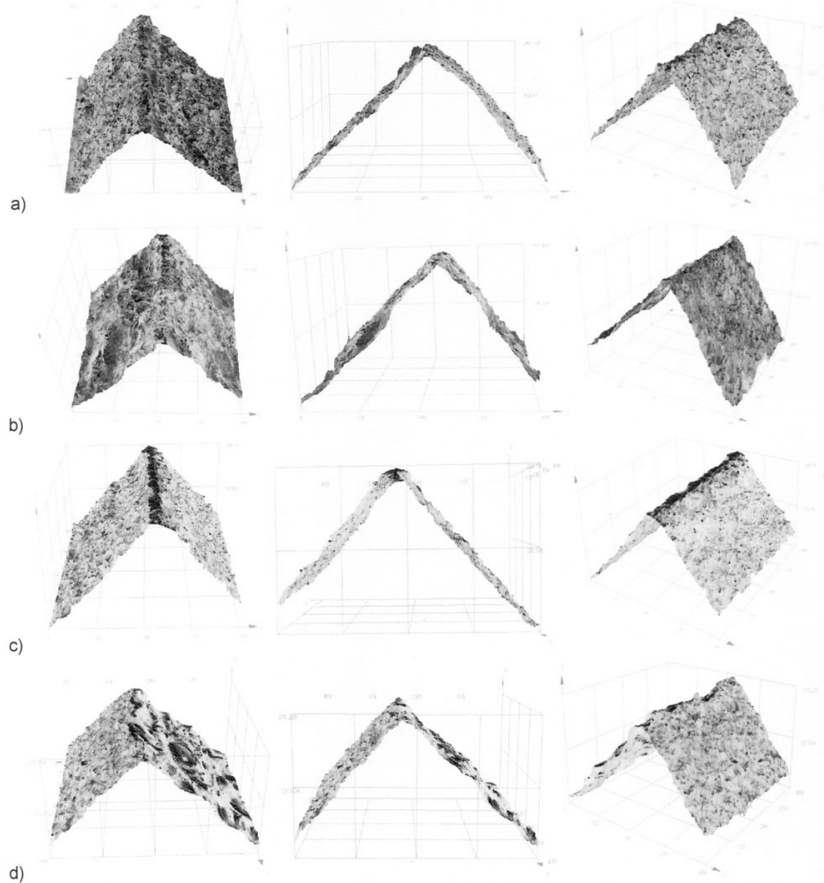

Figure 4. Microstructure images of edges of cubic superalloy samples after wire EDM: a) Hastelloy X b) AZ31 Mg alloy, c) Inconel 617, d) Titanium 5553 ß alloy (magnification $100 \times$ ).

Bild 4. Bilder der Mikrostruktur der Kanten der Würfel nach elektroerosivem Drahtschneiden folgender Metalllegierungen: a) Hastelloy X, b) Magnesium AZ31-Legierung, c) Inconel 617, d) Titan 5553 ß-Legierung (100-fache Vergrößerung).

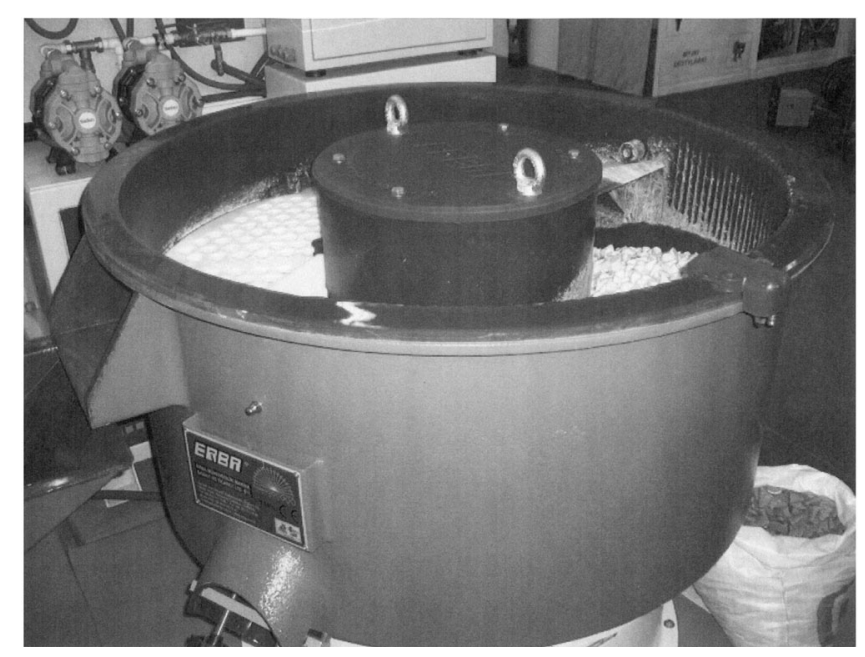

Figure 5. Vibro-abrasive machine (Erba Company) with ceramic shaped stones used for finishing of aircraft alloys (Marbad Ltd. Company, Warsaw, Poland).

Bild 5. Anlage zur Fertigbearbeitung mit Vibrationsschleiftechnik (Erba Company) zusammen mit keramischen Schleifmitteln (Firma Marbad, Warschau, Polen). a)

b)

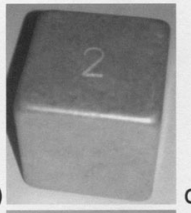

a)

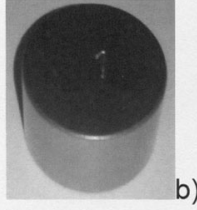

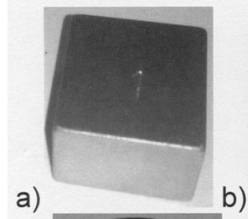

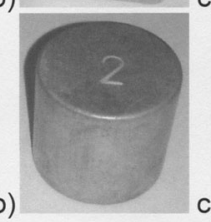

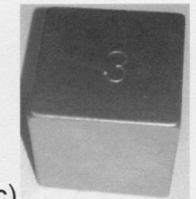

)

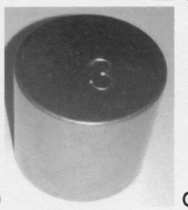

d)

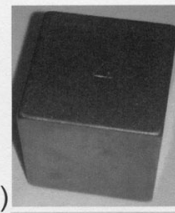

d)

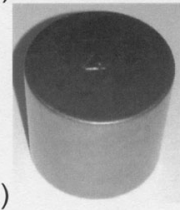

Figure 6. Exemplary pictures of cubic and cylindrical superalloy samples after vibro-abrasive machining (finishing): a) Hastelloy X, b) AZ31Mg alloy, c) Inconel 617, d) Titanium 5553 B alloy (magnification $5 \times$ ).

Bild 6. Beispielbilder von Würfel und Zylinder folgender Metalllegierungen nach Fertigbearbeitung mit Vibrationsschleiftechnik: a) Hastelloy X, b) Titan 5553 ß-Legierung (5-fache Vergrößerung).
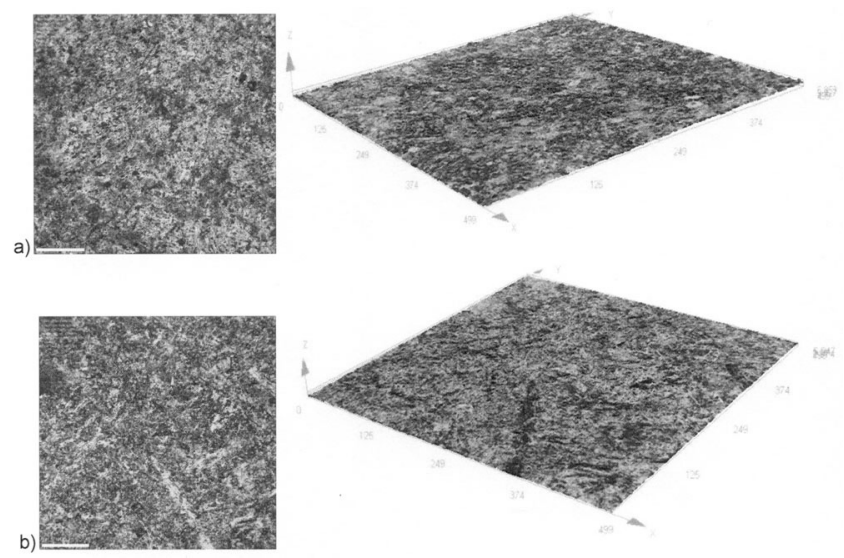

Figure 7. Exemplary microstructure images of cubic superalloy samples after vibro-abrasive machining (finishing): a) AZ31 Mg alloy, b) Titanium 5553 B alloy (magnification 100×).

Bild 7. Beispielbilder der Mikrostruktur folgender Metalllegierungen nach Fertigbearbeitung mit Vibrationsschleiftechnik: a) Magnesium AZ31-Legierung b) Titan 5553 ß-Legierung (100fache Vergrößerung).

wire electrical discharge machining process have confirmed that an increase of the power of the electric impulse generator (increase of voltage and intensity of electric current) has decreased morphology of these alloys. Morphology of surface layers of samples after the wire electrical discharge machining have shown presence of micro craters and weld penetrations caused by electric spark discharges. The depth of these micro craters depends on generator power and spark discharges. Stereometric surface layer parameters $\left(S_{z}, S_{p}, S_{v}, S_{q}, S_{a}\right)$ of superalloy samples after wire 


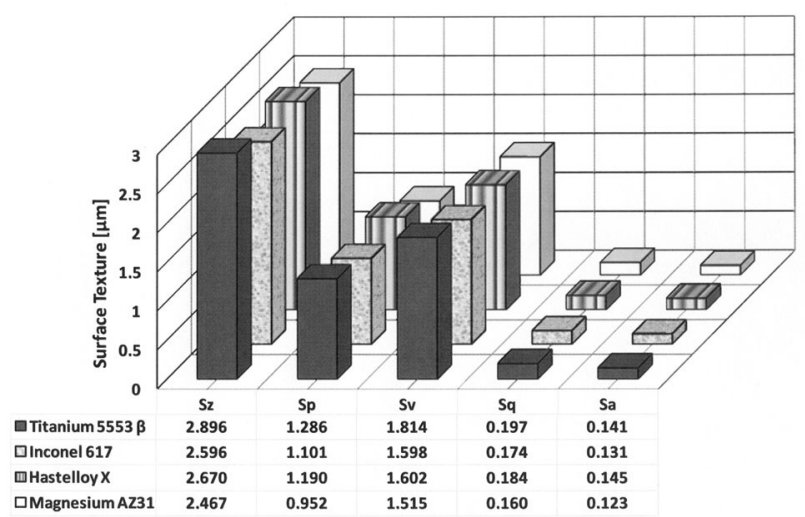

Figure 8. Stereometric surface layer parameters $\left(S_{z}, S_{p}, S_{v}\right.$, $S_{q}, S_{a}$ ) of superalloy samples after vibro-abrasive machining (finishing).

Bild 8. Stereometrische Parameter der Oberfläche $\left(S_{z}, S_{p}\right.$, $S_{v}, S_{q}, S_{a}$ ) der Metalllegierungen nach Fertigbearbeitung mit Vibrationsschleiftechnik.

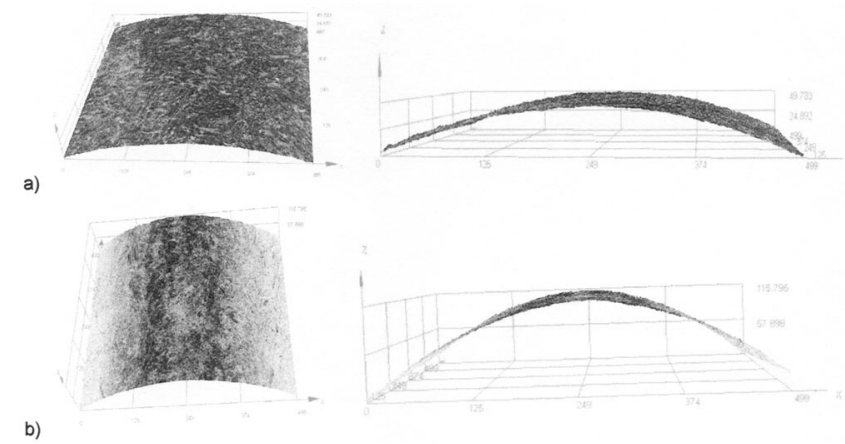

Figure 9. Exemplary microstructure images of edges of cubic superalloy samples after vibro-abrasive machining (finishing): a) AZ31 Mg alloy, b) Titanium 5553 B alloy (magnification $100 \times$ ).

Bild 9. Bilder der Mikrostruktur der Kanten der Würfel folgender Metalllegierungen nach Fertigbearbeitung mit Vibrationsschleiftechnik: a) Magnesium AZ31-Legierung b) Titan 5553 ß-Legierung (100-fache Vergrößerung).

electrical discharge machining have been rather high however the best results have been observed for AZ31 magnesium alloy $\left(S_{a}=1.535 \mu \mathrm{m}\right)$ and the worst for Hastelloy X $\left(S_{a}=2.040 \mu \mathrm{m}\right)$. After vibro-abrasive finishing all hard machinable samples have been characterized by smooth surface without visible tool marks and low roughness. Stereometric surface layer parameters $\left(S_{z}, S_{p}, S_{v}, S_{q}, S_{a}\right)$ of superalloy samples after this stage of machining have been very low comparing to wire electrical discharge machining. It has been observed the following significant decrease of $S_{a}$ parameters respectively: for titanium beta and Hastelloy $\mathrm{X}-$
14 times, for Inconel 617-13 times and for AZ31 magnesium alloy -12 times. After vibro-abrasive finishing once again the best results have been observed for AZ31 magnesium alloy $\left(S_{a}=0.123 \mu \mathrm{m}\right)$ and a little bit worse for Hastelloy $\mathrm{X}\left(S_{a}=0.145 \mu \mathrm{m}\right)$ but these parameters are extremely low and can be compared to parameters after typical polishing process. It means that vibro-abrasive technology allows for polishing of hard machinable materials like samples made of aircraft alloys and is very useful especially for samples of complicated shapes.

\section{References}

[1] M. Gołąbczak, Estimation of Carbon Coatings Manufactured on Magnesium Alloys, Special Issue on Magnesium Alloys, Edited by W. Monteiro, Intech, Croatia, 2011.

[2] M. Gołąbczak, R. Święcik, A. Gołąbczak, C. Nouveau, P. Jacquet, Materialwiss. Werkstofftech. 2018, 49, 568.

[3] K. Oczoś, A. Kawalec, Shaping of light metals, PWN, Poland, 2012.

[4] H.A-G. El-Hofy, Fundamentals of Machining Processes, CRC Press, UK, 2014.

[5] K. Woźniak, Surface Machining in Smoothing Machines, WNT, Poland, 2017.

[6] G.T. Smith, Cutting Tool Technology, Springer, UK, 2008.

[7] W.B. Rowe, Principles of Modern Grinding Technology, Elsevier, USA, 2009.

[8] M. Gołąbczak, Modelling of the Surface Morphology by Means of 2D Numerical Filters, Mechanical and Materials Engineering of Modern Structure and Component Design, Edited by A. Öchsner and $\mathrm{H}$. Altenbach, Springer, Germany, 2015.

[9] A. Gołąbczak, A. Konstantynowicz, M. Gołąbczak, DDF. 2014, 354, 101.

[10] A. Gołąbczak, A. Konstantynowicz, M. Gołąbczak, DDF. 2015, 364, 44.

[11] A. Gołąbczak, M. Gołąbczak, A. Konstantynowicz, DDF. 2015, 365, 63.

[12] M. Gołąbczak, A. Gołąbczak, A. Konstantynowicz, $D D F$, 2016, 371, 43. 